\title{
Strontium ranelate: A novel mode of action leading to renewed bone quality
}

\author{
Patrick Ammann
}

Received: 29 October 2004/ Accepted: 4 November 2004/Published online: 2 December 2004

(C) International Osteoporosis Foundation and National Osteoporosis Foundation 2004

\begin{abstract}
Various bone resorption inhibitors and bone stimulators have been shown to decrease the risk of osteoporotic fractures. However, there is still a need for agents promoting bone formation by inducing positive uncoupling between bone formation and bone resorption. In vitro studies have suggested that strontium ranelate enhances osteoblast cell replication and activity. Simultaneously, strontium ranelate dose-dependently inhibits osteoclast activity. In vivo studies indicate that strontium ranelate stimulates bone formation and inhibits bone resorption and prevents bone loss and/or promotes bone gain. This positive uncoupling between bone formation and bone resorption results in bone gain and improvement in bone geometry and microarchitecture, without affecting the intrinsic bone tissue quality. Thus, all the determinants of bone strength are positively influenced. In conclusion, strontium ranelate, a new treatment of postmenopausal osteoporosis, acts through an innovative mode of action, both stimulating bone formation and inhibiting bone resorption, resulting in the rebalancing of bone turnover in favor of bone formation. Strontium ranelate increases bone mass while preserving the bone mineralization process, resulting in improvement in bone strength and bone quality.
\end{abstract}

Keywords Bone quality $\cdot$ Strontium ranelate

\section{Introduction}

Various bone resorption inhibitors and bone stimulators have been shown to decrease the risk of osteoporotic

P. Ammann

Division of Bone Diseases, WHO Collaborating Center for Osteoporosis Prevention, Department of Rehabilitation and Geriatrics, University Hospital of Geneva,

1211 Geneva 14, Switzerland

E-mail: Patrick.Ammann@hcuge.ch

Tel.: + 41-2237-29950

Fax: + 41-22-3829973 fractures. However, there is still a need for agents promoting bone formation by inducing positive uncoupling between bone formation and bone resorption. Strontium ranelate (Protelos) simultaneously increases bone formation and decreases bone resorption, resulting in the rebalancing of bone turnover in favor of bone formation. This unique mode of action leads to positive effects on bone strength and its determinants and could certainly explain the clinical effects of strontium ranelate. It has recently been demonstrated that it reduces both vertebral and hip fracture risk and so is a good candidate $[1,2]$.

\section{Bone strength and its determinants}

The aim of any anti-osteoporotic treatment is to improve bone strength and thus to decrease the risk of fracture [3-5]. In humans, the approach to evaluating bone strength is the recording of the fracture rate, which implies a large group of patients. Thus, a fracture is not only due to decreased bone mineral mass or alteration in the microarchitecture but is also related to falls, as a result of loss of balance, inappropriate protective responses, or muscle weakness [3-5]. Careful and specific investigation in animal models of treatments against osteoporosis with regard to bone strength and its determinants is therefore of major importance.

Bone strength is determined by bone geometry, cortical thickness and porosity, trabecular bone morphology, and intrinsic properties of bone tissue. Bone strength is indirectly estimated by bone mineral density (BMD) using dual energy X-ray absorptiometry (DXA). Since DXA-based BMD accounts for $60-70 \%$ of the variation in bone strength, some important factors are not captured by DXA in the progression of osteoporosis and the effects of anti-osteoporotic treatment. Geometry and trabecular microarchitecture have also to be taken into account. Thus, the assessment of intrinsic mechanical quality of bone tissue should provide better understanding of the role of tissue quality in determining bone strength. 
More recently, a nanoindentation technique has been applied to investigate tissue quality by measuring both hardness and elasticity of dry and wet bone tissue with a high spatial resolution [6, 7]. Nanoindentation consists of compressing a pyramidal diamond tip into a material and simultaneously recording force and displacement with $\mu \mathrm{N}$ and $\mathrm{nm}$ resolution. From the resulting forcedisplacement curves, hardness, the maximal force per unit area, dissipated energy, and indentation modulus - a purely elastic property - can be calculated. The nanoindentation method allows the mechanical properties of single bone structural units to be quantified. Few results are currently available, but local elastic properties of bone structural units have been found to vary significantly among individuals and anatomical locations [7-11]. Little correlation was found between age and the elastic properties of bone tissue $[9,10]$. Nanoindentation could represent a tool of major importance for evaluating the tissue quality and for better understanding of the mechanism by which treatments of osteoporosis could improve bone strength. In the future, this could help to investigate, on bone biopsy, the contribution of tissue quality in the determination of bone fragility.

The careful investigation of all of these determinants of bone strength (bone tissue included) should be considered in the pathophysiology of osteoporosis and in the mechanisms of action of anti-osteoporotic drugs.

\section{Effects of inhibitors of bone resorption on bone strength and its determinants}

Most of the clinical studies on inhibitors of bone resorption like estrogen, selective estrogen receptor modulators (SERMs), or bisphosphonates have shown an association between the increment in areal BMD and the decreased risk of fracture, but the modifications are not always commensurate [12-14]. Indeed, while BMD seems to be a good predictor of bone strength, it could be confusing in certain conditions of treatment. Raloxifene and alendronate treatment are both associated with a reduction in vertebral fracture close to $50 \%$, but the effect on BMD of treatment with raloxifene $(+3 \%)$ is less pronounced than that of treatment with alendronate $(+8 \%)[12,15-17]$. In a recently reported animal study [18], the administration of inhibitors of bone resorption (SERMs or bisphosphonate) restored the mechanical resistance and the areal mineral density after ovariectomy, but did not correct cancellous bone mass. These agents, by differently modulating bone turnover through different mechanisms, could increase the intrinsic properties of bone and cancellous bone architecture rather than the cancellous bone mass. These findings thus imply that not only bone quantity but also intrinsic properties of bone and cancellous architecture play an important role in the mechanical resistance to fracture [18].
One parameter, which should also be considered, is the degree of mineralization. Increased bone strength is observed on bisphosphonate therapy, without significant modification of bone mass or trabecular volume as evaluated by histomorphometry [19-21]. A more homogeneous degree of mineralization is observed, which could account for the increment in BMD and bone strength. The rate of bone remodeling could also be implicated. Clinical studies indicate that markers of bone remodeling could be independent predictors of the risk of fracture [22]. By different distribution of stress in relation to the volume of bone in a phase of remodeling, a high remodeling rate could jeopardize mechanical strength. Alternatively, decreased bone remodeling could influence trabecular bone geometry and the degree of mineralization of the matrix formed on treatment.

\section{Effects of stimulators of bone formation on bone strength and its determinants}

Fluoride treatment induced a major increase in BMD $(+10 \% /$ year) but did not reduce the incidence of fracture [23-29]. Overall analysis of the current preclinical studies indicates that fluoride does not improve bone strength in several animal models including rats, minipigs, and rabbits, although it can increase spinal bone mass as in humans, at least in the so-called "good responders." Several possible explanations have been proposed for the discrepancy, among them the severity of osteoporosis at the beginning of treatment, the absolute daily doses, the dosing schedule, and the duration of treatment. Thus, the quality of the crystal obtained on fluoride treatment might also be responsible for this poor effect on bone strength despite a positive effect on bone mass.

Other stimulators of bone formation [30-40] such as insulin-like growth factor 1 (IGF-I), growth hormone, or parathyroid hormone (PTH) stimulate the periosteal apposition and increase the external diameter of long bones. This expansion of the outer diameter of long bone is associated with a marked increase in bone strength. When associated with an inhibitor of bone resorption, an increase in cortical thickness can also be observed and corresponds to an inhibition of endosteal bone resorption [31,32], thereby participating in the improvement in bone strength. An expansion of bone diameter could also be observed in humans. Thus, during growth, bone diameter is influenced by the nutritional environment, as for example by calcium/ phosphate salt supplements [41].

On PTH treatment, an increased bone area can even be detected. An excess of growth hormone, as in acromegaly, increases bone size. Thus, an expansion of bone size is possible in adults, but the specific role of this modification in the risk of fracture remains to be established. These modifications of bone mass and size also resulted in a major increase in BMD and improvement in microarchitecture. 


\section{Effect of the innovative agent strontium ranelate on bone strength and its determinants}

In vitro studies have suggested that strontium ranelate enhances osteoblast cell replication and activity [42]. Simultaneously, strontium ranelate dose-dependently inhibits osteoclast activity [43, 44]. In vivo studies in various rodent models like intact animals, model of immobilization, or ovariectomy-induced osteoporosis, suggest the same effects: strontium ranelate stimulates bone formation and inhibits bone resorption in mice and rats [45-49] and prevents bone loss and/or promotes bone gain, as investigated by histomorphometry, DXA, and biomechanics [50].

In intact female rats, a 2-year period of exposure to strontium ranelate mixed in the diet induced a dosedependent increase in bone mechanical properties at the level of the vertebral body, which contains a large proportion of trabecular bone, and at the level of the midshaft femur, which mainly contains cortical bone [50]. The increase in bone strength was related to a dosedependent increase in bone mass and bone volume and can also be due to an improvement in bone tissue quality. The increase in trabecular bone volume, trabecular number, trabecular thickness, and cortical thickness, as assessed at the tibia level by histomorphometry, is in agreement with a net gain in bone tissue mass. Strontium ranelate improves bone geometry by increasing external diameter and cortical thickness of the long bone through periosteal apposition.

The increment in bone mechanical properties was characterized by an increase in ultimate strength but also by a dramatic improvement in energy to failure, which was essentially due to an increment in plastic energy. Such modifications observed on strontium ranelate treatment are in good agreement with an improvement in intrinsic bone quality and also in trabecular bone mass, leading to greater bone resistance. These results strongly suggest that new bone formed following strontium ranelate treatment is able to withstand greater deformation before fracture, while possessing similar elastic properties to normal bone. Furthermore, a 2-year exposure to strontium ranelate did not cause any alteration in bone mineralization, as assessed by histomorphometry, or bone stiffness. Recent data indicate that intrinsic bone tissue quality in rats treated lifelong with strontium ranelate was similar to that of intact rats of the same age [51]. The same results are obtained at the level of mineralization, which is not affected by bone balance and bone mass. It has been shown that the distribution of strontium ranelate in bone is dependent on the dose, the duration of exposure, gender, and skeletal site. Strontium is distributed in calcified matrix and is easily exchangeable from bone mineral, being slightly linked to mature crystals through ionic substitutions. Strontium is heterogeneously distributed in bone with a higher concentration in new than in old bone, in both trabecular bone and cortical bone [52].
This positive uncoupling between bone formation and bone resorption results in bone gain and improvement in bone geometry and microarchitecture and, consequently, improvement in bone strength. These observations in animals fully predict what is observed in postmenopausal women. Indeed, strontium ranelate treatment stimulates bone formation and decreases bone resorption in postmenopausal osteoporotic women, resulting in a decrease in vertebral and hip fracture rates $[1,2]$. Thus, strontium ranelate is the first anti-osteoporotic agent combining both a stimulation of bone formation and an inhibition of bone resorption for an optimal effect on all the determinants of bone strength.

\section{Conclusion}

Strontium ranelate, a new treatment of postmenopausal osteoporosis, acts through an innovative mode of action, both stimulating bone formation and inhibiting bone resorption, resulting in a rebalancing of bone turnover in favor of bone formation.

Strontium ranelate increases bone mass while preserving the bone mineralization process, resulting in improvement in bone strength and bone quality.

\section{References}

1. Meunier PJ, Roux C, Seeman E, Ortolani S, Badurski JE, Spector TD, Cannata J, Balogh A, Lemmel EM, Pors-Nielsen S, Rizzoli R, Genant HK, Reginster JY (2004) The effects of strontium ranelate on the risk of vertebral fracture in women with postmenopausal osteoporosis. N Engl J Med 350:459468

2. Rizzoli R, Reginster JY, Diaz-Curiel M et al (2004) Patients at high risk of hip fracture benefit from treatment with strontium ranelate. Osteoporos Int 15(S1):OC39

3. Ammann P, Rizzoli R, Bonjour JP (1998) Preclinical evaluation of new therapeutic agents for osteoporosis. In: Meunier PJ (ed) Osteoporosis: diagnosis and management. Martin Dunitz, London, pp 257-273

4. Ammann P, Rizzoli R, Bonjour JP (1998) Protein malnutritioninduced bone loss is associated with alteration of growth hormone-IGF-I axis and with estrogen deficiency in adult rats. Osteoporos Int 8(S3): 10

5. Bonjour JP, Ammann P, Rizzoli R (1999) Importance of preclinical studies in the development of drugs for treatment of osteoporosis: a review related to the 1998 WHO guidelines. Osteoporos Int 9:379-293

6. Rho JY, Tsui YT, Pharr GM (1997) Elastic properties of human cortical and trabecular lamellar bone measured by nanoindentation. Biomaterials 18/20:1325-1330

7. Zysset PK, Guo XE, Hoffler CE, Moore KE, Goldstein SA (1999) Elastic modulus and hardness of cortical and trabecular bone lamellae measured by nanoindentation in the human femur. J Biomech 32:1005-1012

8. Roy ME, Rho JY, Tsui YT, Evans NS, Pharr GM (1999) Mechanical and morphological variation of the human lumbar vertebral cortical and trabecular bone. J Biomed Mater Res 44:191-199

9. Hoffler CE, Moore KE, Kozloff K, Zysset PK, Brown MB, Goldstein SA (2000) Heterogeneity of bone lamellar-level elastic moduli. Bone 26:603-609 
10. Hoffler CE, Moore KE, Kozloff K, Zysset PK, Goldstein SA (2000) Age, gender, and bone lamellae elastic moduli. J Orthop Res 18:432-437

11. Hengsberger S, Boivin G, Zysset PK (2002) Morphological and mechanical properties of bone structural units: a two-case study. JSME Series C 45/4:936-43

12. Ettinger B, Black DM, Mitlak BH, Knickerbocker RK, Nickelsen T, Genant HK, Christiansen C, Delmas PD, Zanchetta JR, Stakkestad J, Gluer CC, Krueger K, Cohen FJ, Eckert S, Ensrud KE, Avioli LV, Lips P, Cummings SR (1999) Reduction of vertebral fracture risk in postmenopausal women with osteoporosis treated with raloxifene: results from a 3-year randomized clinical trial. Multiple Outcomes of Raloxifene Evaluation (MORE) Investigators. JAMA 282:637645

13. Riggs BL, Khosla S, Melton LJ 3rd (2002) Sex steroids and the construction and conservation of the adult skeleton. Endocr Rev 23:279-302

14. Hochberg MC, Greenspan S, Wasnich RD, Miller P, Thompson DE, Ross PD (2002) Changes in bone density and turnover explain the reductions in incidence of nonvertebral fractures that occur during treatment with antiresorptive agents. J Clin Endocrinol Metab 87:1586-1592

15. Liberman UA, Weiss SR, Broll J, Minne HW, Quan H, Bell NH, Rodriguez-Portales J, Downs RW Jr, Dequeker J, Favus M (1995) Effect of oral alendronate on bone mineral density and the incidence of fractures in postmenopausal osteoporosis. The Alendronate Phase III Osteoporosis Treatment Study Group. N Engl J Med 333:1437-1443

16. Black DM, Cummings SR, Karpf DB, Cauley JA, Thompson DE, Nevitt MC, Bauer DC, Genant HK, Haskell WL, Marcus R, Ott SM, Torner JC, Quandt SA, Reiss TF, Ensrud KE (1996) Randomised trial of effect of alendronate on risk of fracture in women with existing vertebral fractures. Fracture Intervention Trial Research Group. Lancet 348:1535-1541

17. Delmas PD, Bjarnason NH, Mitlak BH, Ravoux AC, Shah AS, Huster WJ, Draper M, Christiansen C (1997) Effects of raloxifene on bone mineral density, serum cholesterol concentrations, and uterine endometrium in postmenopausal women. N Engl J Med 337:1641-1647

18. Bourrin S, Ammann P, Bonjour JP, Rizzoli R (2002) Recovery of proximal tibia bone mineral density and strength, but not cancellous bone architecture, after long-term bisphosphonate or selective estrogen receptor modulator therapy in aged rats. Bone 30:195-200

19. Chavassieux PM, Arlot ME, Reda C, Wei L, Yates AJ, Meunier PJ (1997) Histomorphometric assessment of the long-term effects of alendronate on bone quality and remodeling in patients with osteoporosis. J Clin Invest 100:1475-1480

20. Meunier PJ, Boivin G (1997) Bone mineral density reflects bone mass but also the degree of mineralization of bone: therapeutic implications. Bone 21:373-377

21. Boivin GY, Chavassieux PM, Santora AC, Yates J, Meunier PJ (2000) Alendronate increases bone strength by increasing the mean degree of mineralization of bone tissue in osteoporotic women. Bone 27:687-694

22. Garnero P, Delmas PD (1996) New developments in biochemical markers for osteoporosis. Calcif Tissue Int 59 [Suppl 1]:S2-9

23. Pak CY, Sakhaee K, Zerwekh JE, Parcel C, Peterson R, Johnson K (1989) Safe and effective treatment of osteoporosis with intermittent slow release sodium fluoride: augmentation of vertebral bone mass and inhibition of fractures. J Clin Endocrinol Metab 68:150-159

24. Hedlund LR, Gallagher JC (1989) Increased incidence of hip fracture in osteoporotic women treated with sodium fluoride. J Bone Miner Res 4:223-225

25. Schnitzler CM, Wing JR, Gear KA, Robson HJ (1990) Bone fragility of the peripheral skeleton during fluoride therapy for osteoporosis. Clin Orthop:268-275
26. Riggs BL, Hodgson SF, O'Fallon WM, Chao EY, Wahner HW, Muhs JM, Cedel SL, Melton LJ 3rd (1990) Effect of fluoride treatment on the fracture rate in postmenopausal women with osteoporosis. N Engl J Med 322:802-809

27. Pouilles JM, Tremollieres F, Causse E, Louvet JP, Ribot C (1991) Fluoride therapy in postmenopausal osteopenic women: effect on vertebral and femoral bone density and prediction of bone response. Osteoporos Int 1:103-109

28. Turner $\mathrm{CH}$, Owan I, Brizendine EJ, Zhang W, Wilson ME, Dunipace AJ (1996) High fluoride intakes cause osteomalacia and diminished bone strength in rats with renal deficiency. Bone 19:595-601

29. Meunier PJ, Sebert JL, Reginster JY, Briancon D, Appelboom T, Netter P, Loeb G, Rouillon A, Barry S, Evreux JC, Avouac B, Marchandise X (1998) Fluoride salts are no better at preventing new vertebral fractures than calcium-vitamin $D$ in postmenopausal osteoporosis: the FAVOStudy. Osteoporos Int $8: 4-12$

30. Jorgensen PH, Bak B, Andreassen TT (1991) Mechanical properties and biochemical composition of rat cortical femur and tibia after long-term treatment with biosynthetic human growth hormone. Bone 12:353-359

31. Ammann P, Rizzoli R, Muller K, Slosman D, Bonjour JP (1993) IGF-I and pamidronate increase bone mineral density in ovariectomized adult rats. Am J Physiol 265:E770-E776

32. Ammann P, Rizzoli R, Meyer JM, Bonjour JP (1996) Bone density and shape as determinants of bone strength in IGF-I and/or pamidronate-treated ovariectomized rats. Osteoporos Int 6:219-227

33. Oxlund H, Ejersted C, Andreassen TT, Torring O, Nilsson MH (1993) Parathyroid hormone (1-34) and (1-84) stimulate cortical bone formation both from periosteum and endosteum. Calcif Tissue Int 53:394-399

34. Ejersted C, Andreassen TT, Oxlund H, Jorgensen PH, Bak B, Haggblad J, Torring O, Nilsson MH (1993) Human parathyroid hormone (1-34) and (1-84) increase the mechanical strength and thickness of cortical bone in rats. $\mathrm{J}$ Bone Miner Res 8:1097-1101

35. Mosekilde L, Danielsen CC, Gasser J (1994) The effect on vertebral bone mass and strength of long-term treatment with antiresorptive agents (estrogen and calcitonin), human parathyroid hormone-(1-38), and combination therapy, assessed in aged ovariectomized rats. Endocrinology 134:2126-2134

36. Mosekilde L, Sogaard CH, McOsker JE, Wronski TJ (1994) PTH has a more pronounced effect on vertebral bone mass and biomechanical competence than antiresorptive agents (estrogen and bisphosphonate) - assessed in sexually mature, ovariectomized rats. Bone 15:401-408

37. Li M, Wronski TJ (1995) Response of femoral neck to estrogen depletion and parathyroid hormone in aged rats. Bone 16:551557

38. Andreassen TT, Jorgensen PH, Flyvbjerg A, Orskov H, Oxlund $H$ (1995) Growth hormone stimulates bone formation and strength of cortical bone in aged rats. J Bone Miner Res 10:1057-1067

39. Andreassen TT, Oxlund H (2000) The influence of combined parathyroid hormone and growth hormone treatment on cortical bone in aged ovariectomized rats. J Bone Miner Res $15: 2266-2275$

40. Toromanoff A, Ammann P, Riond JL (1998) Early effects of short-term parathyroid hormone administration on bone mass, mineral content, and strength in female rats. Bone 22:217-223

41. Bonjour JP, Chevalley T, Ammann P, Slosman D, Rizzoli R (2001) Gain in bone mineral mass in prepubertal girls 3.5 years after discontinuation of calcium supplementation: a follow-up study. Lancet 358:1208-1212

42. Canalis E, Hott M, Deloffre P, Tsouderos Y, Marie PJ (1996) The divalent strontium salt S12911 enhances bone cell replication and bone formation in vitro. Bone 18:517-523

43. Baron R, Tsouderos Y (2002) In vitro effects of S12911-2 on osteoclast function and bone marrow macrophage differentiation. Eur J Pharmacol 450:11-17 
44. Takahashi N, Sasaki T, Tsouderos Y, Suda T (2003) S 12911-2 inhibits osteoclastic bone resorption in vitro. J Bone Miner Res 18:1082-1087

45. Delannoy P, Bazot D, Marie PJ (2002) Long-term treatment with strontium ranelate increases vertebral bone mass without deleterious effect in mice. Metabolism 51:906-911

46. Grynpas MD, Hamilton E, Cheung R, Tsouderos Y, Deloffre P, Hott M, Marie PJ (1996) Strontium increases vertebral bone volume in rats at a low dose that does not induce detectable mineralization defect. Bone 18:253-259

47. Marie PJ, Hott M, Modrowski D, De Pollak C, Guillemain J, Deloffre P, Tsouderos Y (1993): An uncoupling agent containing strontium prevents bone loss by depressing bone resorption and maintaining bone formation in estrogen-deficient rats. J Bone Miner Res 8:607-615

48. Bain S, Shen V, Hara P, Dupin-Roger I (2003) Long-term treatment with strontium ranelate increases histomorphometric indices of bone formation in ovariectomized rats. J Bone Miner Res 18 [suppl 2]:S277
49. Hott M, Deloffre P, Tsouderos Y, Marie PJ (2003) S12911-2 reduces bone loss induced by short-term immobilization in rats. Bone 33:115-123

50. Ammann P, Shen V, Robin B, Mauras Y, Bonjour JP, Rizzoli $\mathrm{R}$ (2004) Strontium ranelate improves bone resistance by increasing bone mass and improving architecture in intact female rats. J Bone Miner Res 19(12):2012-2020

51. Ammann P, Barrauld S, Dayer R, Dupin-Roger I, Rizzoli R (2004) Strontium ranelate increases bone quality in rats: improvement of the microarchitecture and preservation of the intrinsic bone quality. J Bone Miner Res 19 [Suppl 1]:S178

52. Boivin G, Deloffre P, Perrat B, Panczer G, Boudeulle M, Mauras Y, Tsouderos Y, Meunier PJ (1996), Strontium distribution and interactions with bone mineral in monkey iliac bone after strontium salt (S12911) administration. J Bone Miner Res 11:1302-1311 